\title{
The Behaviours of the Brick-Masonry Infilled RC Frame Structure under Reversed Cyclic Lateral Loading
}

\author{
Maidiawati $^{\#}$, Yasushi Sanada ${ }^{*}$, Jafril Tanjung ${ }^{+}$ \\ ${ }^{\#}$ Civil Engineering Department, Padang Institute of Technology, Padang, 25143, Indonesia \\ E-mail: maidiawati@itp.ac.id
}

*Graduate School of Engineering, Osaka University, Suita, Osaka, 565-0871, Japan

E-mail: sanada@arch.eng.osaka-u.ac.jp

${ }^{+}$Civil Engineering Department, Andalas University, Kampus Limau Manis, Padang, 25163, Indonesia

E-mail: jafriltanjung@eng.unand.ac.id

\begin{abstract}
The experimental study for investigating the seismic responses of the Reinforced Concrete (RC) frame specimens is presented in this paper. Regarding this experimental, two one-bay and scaled-down specimens have been prepared and tested, i.e., RC bare frame and RC frame with brick masonry infill. The masonry infilled RC frame specimen was the RC frame which was infilled by the extracted brick masonry wall from the survive RC building in Padang city due to September 2007 Sumatra earthquake. These both of specimens, obviously, represent the typical low-rise RC building in West Sumatra, Indonesia. These specimens were tested to the constant vertical load, and lateral static reversed cyclic loading in the structural testing facilities. The lateral loading was applied incrementally and controlled by the drift angle of the specimens. The drift angle is the ratio between the lateral displacement of the top of the column and the column height of the specimen. The applied incremental lateral load and displacements at several points on the specimens were measured and recorded during the testing. The observation of the major cracks and its propagation were also conducted to identify the failure mechanism of the RC frame specimens. Comparison of the testing results for both of the specimens suggests that the masonry brick infill contributed to significantly increase the dissipating energy capacity, lateral strength, and stiffness of overall RC frames. On the other hand, unfortunately, the ductility performance of the brick masonry infilled RC frame specimen was decreasing. The presence of brick masonry infill in the RC frame seems to control the failure mechanism of the RC frame, reduces the deformation capacity of the boundary column, and alters the lateral and axial deformations of boundary columns.
\end{abstract}

Keywords - brick masonry infill; dissipated energy; lateral strength; RC frame; seismic response.

\section{INTRODUCTION}

Non-structural masonry brick walls are commonly used as infill in the low and medium multi-story RC buildings in seismic-prone regions such as Indonesia. Based on postearthquake investigations it was obtained that many $\mathrm{RC}$ buildings suffered severe damage [1]-[3], but RC buildings with brick masonry infills showed better performance [1]. It indicates that brick masonry infills had a contribution to the seismic performance of RC frame structure. Large numbers of the experimental studies have been conducted by researchers to explore the contribution of brick masonry infills to seismic responses of the RC as well-reported in [4][6]. Besides, various analytical approaches have also been developed for evaluating the performance of masonry infill and their interaction to surrounding of the $\mathrm{RC}$ frame structures [7]-[11]. Nevertheless, in most cases, the design of the seismic resistance structures has not taken into account the presence of brick masonry infill. The brick masonry wall is commonly assumed as the non-structural components.

Since 2004, many destructive earthquakes have occurred in the western part of Sumatra Island. For instance, the Sumatra earthquakes occurred in September 2007 and September 2009 [2]. The large numbers of RC buildings using brick masonry walls have suffered severe damage due to these earthquakes. The exemplary damages of the RC building with brick masonry infill wall in Padang city and nearby were assessed after Sumatera earthquake 2007, as reported in [1]. This post-earthquake investigation focused on the damages of two identical RC frame buildings. One of the buildings totally collapsed, while another one was moderately damaged and survived. Actually, the analytical 
study for evaluating these damaged RC buildings has been conducted by authors as explained in [1] which referred to Japanese's standard [12]. The presence of the brick masonry infill in RC frames was considered in its study. In conclusion, although the brick masonry infilled was treated as a nonstructural component, but gave a significant contribution to resist the seismic motion and can protect the early collapse of the RC buildings. Several questions still remain no definite answers after the post-earthquake investigation works, such as how the failure mechanism of the brick masonry walls and RC frame structures, how large their lateral deformation, lateral strength, their stiffness, and their dissipated energy. Therefore, in this study, the experimental works were conducted to define the influence of the presence of the brick masonry infill to seismic response of the RC frame structures.

\section{MATERIAL AND METHOD}

\section{A. Experimental Works}

\section{1) Test Specimens}

In order to investigate the influences of the presence of the brick masonry infills to the seismic responses of the RC frame structures, a series of experimental works have been conducted under reversed lateral cyclic loading. These works include the tested models of 1/2.5 scale-down of the RC bare frame (BF) and brick masonry infilled RC frame (IF) specimens. These specimens represent the first story of the survived RC building in Padang city during the Sumatra earthquake on September 2007 as shown in Fig. 1(a). The column height was $1000 \mathrm{~mm}$ with cross-sectional of 140x140 mm and using $4 \square 9$ longitudinal rebars and $2 \square 4$ $120 \mathrm{~mm}$ transverse hoop. The detail drawing of the BF specimens is shown in Fig. 2(a).

Especially for the IF specimen, as shown in Fig. 1(b), the brick infill wall panel was extracted from the surviving building and transported to Japan. Furthermore, it brick wall panel was installed in the RC frame specimen in the dimension of $1,420 \mathrm{~mm}$ width and $960 \mathrm{~mm}$ height. Noting that the thickness of the brick wall in IF specimen was remaining in original size, i.e., $140 \mathrm{~mm}$. Due to technical difficulties, the wall thickness was not scaled down. The mortar was blended from cement, sand, and water in volume ratio as 1:4:1.3. The mortar inserted between the brick wall and the RC frame as interface material. The mortar thickness was approximating $20 \mathrm{~mm}$ as it is shown in Fig. 2(b).

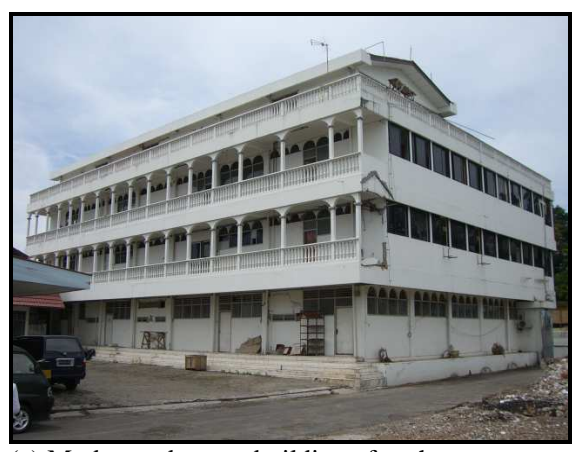

(a) Moderate damage building after the September 2007 Sumatra earthquake

Fig. 1 Preparation of brick wall specimen
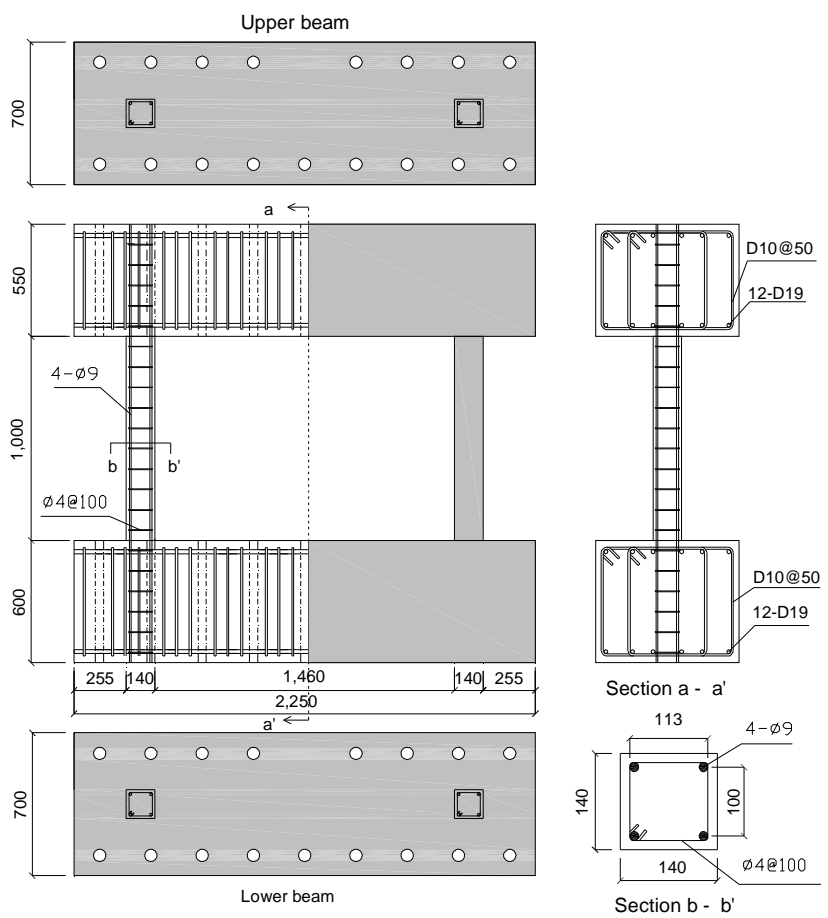

(a) BF specimen

unit: $\mathrm{mm}$
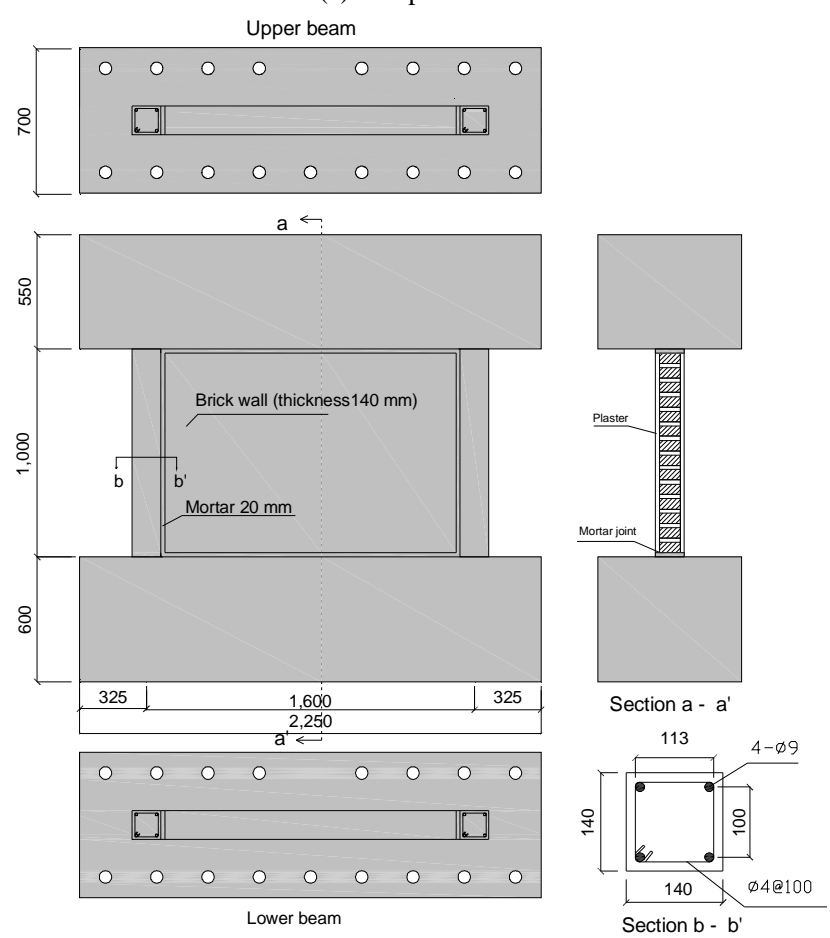

(b) IF specimen

unit: $\mathrm{mm}$

Fig. 2 Detailed drawing of specimens.

\section{2) Material Properties}

In order to define material properties used in this study, the concrete and mortar cylinders, brick masonry prisms, and the steel bars specimens have been prepared and tested using standard material testing. The concrete and mortar cylinders and brick masonry prisms were tested in a compression test, while the steel bars were tested by using a tensile testing machine. The properties of this material are tabulated in Table 1. 
TABLE I

MATERIAL PROPERTIES OF SPECIMENS

\begin{tabular}{|l|c|c|c|}
\hline \multicolumn{5}{|c|}{ Concrete } \\
\hline Specimen & $\begin{array}{c}\text { Compressive } \\
\text { strength } \\
\left(\mathbf{N} / \mathbf{m m}^{2}\right)\end{array}$ & $\begin{array}{c}\text { Tensile } \\
\text { strength } \\
\left(\mathbf{N} / \mathbf{m m}^{2}\right)\end{array}$ & $\begin{array}{c}\text { Young modulus } \\
\left(\mathbf{N} / \mathbf{m m}^{2}\right)\end{array}$ \\
\hline BF & 19.6 & 1.89 & 17862.7 \\
\hline IF & 20.6 & 1.96 & 18968.3 \\
\hline \multicolumn{4}{|c|}{ Masonry prism } \\
\hline Specimen & $\begin{array}{c}\text { Compressive } \\
\text { strength } \\
\left(\mathbf{N} / \mathbf{m m}^{2}\right)\end{array}$ & $\begin{array}{c}\text { Tensile } \\
\text { strength } \\
\left(\mathbf{N} / \mathbf{m m}^{2}\right)\end{array}$ & $\begin{array}{c}\text { Young modulus } \\
\left(\mathbf{N} / \mathbf{m m}^{2}\right)\end{array}$ \\
\hline IF & 2.91 & 0.55 & 789.0 \\
\hline \multicolumn{4}{|c|}{ Mortar } \\
\hline Specimen & $\begin{array}{c}\text { Compressive } \\
\text { strength } \\
\left(\mathbf{N} / \mathbf{m m}^{2}\right)\end{array}$ & $\begin{array}{c}\text { Tensile } \\
\text { strength } \\
\left(\mathbf{N} / \mathbf{m m}^{2}\right)\end{array}$ & $\begin{array}{c}\text { Young modulus } \\
\left(\mathbf{N} / \mathbf{m m}^{2}\right)\end{array}$ \\
\hline $\begin{array}{l}\text { IF (only for } \\
\text { boundaries) }\end{array}$ & 40.8 & 3.33 & $\mathrm{n} . \mathrm{a}$ \\
\hline \multicolumn{4}{|c|}{ Reinforcing bar } \\
\hline Specimen & $\begin{array}{c}\text { Yield strength } \\
\left(\mathbf{N} / \mathbf{m m}^{2}\right)\end{array}$ & $\begin{array}{c}\text { Tensile } \\
\text { strength } \\
\left(\mathbf{N} / \mathbf{m m}^{2}\right)\end{array}$ & $\begin{array}{c}\text { Young modulus } \\
\left(\mathbf{N} / \mathbf{m m}^{2}\right)\end{array}$ \\
\hline$\phi 9$ & 355 & 440 & $2.02 \times 10^{5}$ \\
\hline$\phi 4$ & \multicolumn{4}{|c|}{507} & 631 & $2.14 \times 10^{5}$ \\
\hline
\end{tabular}

\section{B. Test Methods}

\section{1) Loading Method}

The experimental works were conducted by utilizing the structural testing facilities in Toyohashi University of Technology, Japan. The experimental set-up is schematically shown in Fig. 3. The loading system was applied by one horizontal and two vertical jacks. Each jack capacity is 2,000 $\mathrm{kN}$. Two constant vertical forces of $183.4 \mathrm{kN}$ were loaded to specimens which were calculated based on the weight of the $\mathrm{RC}$ building. These vertical forces were equivalent to an approximation of $24 \%$ of the sectional area of column multiplied by the compressive strength of concrete of the survived RC building. The applied lateral reversed cyclic loading to the specimens referred to FEMA 461 standard [13]. The load increment was in drift angle control $\mathrm{R}$, where drift angle $\mathrm{R}$ in degree, i.e., a ratio between the lateral displacement and the column height. The initial cycle is $\mathrm{R}=$ $1 / 800$ and followed by two cycles for every $R=1 / 400,1 / 200$, $1 / 100,1 / 50,1 / 25$, and $1 / 12.5$ as is shown in Fig. 4. During

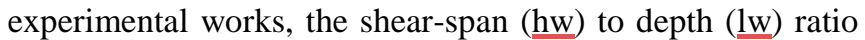
of the specimens was always maintained at 0.75. The experimental work was stopped when the specimen failed.

\section{2) Measurement}

All the displacements were measured by the displacement transducers and recorded by the portable data logger. The set-up of transducers on the specimens is shown in Fig. 5(a), i.e., transducers codes D1 to D25. These displacements include the horizontal, vertical and the diagonal relative displacements, respectively. Besides of them, the strains of reinforcements were measured by the strain gauges. The arrangement of the strain gauges pasted on the rebars is shown in Fig. 5(b). During applied loading, the cracks occurred on the specimens were observed, such as cracks on columns and the brick walls as well. These cracks were marked at the initial and maximum positions.

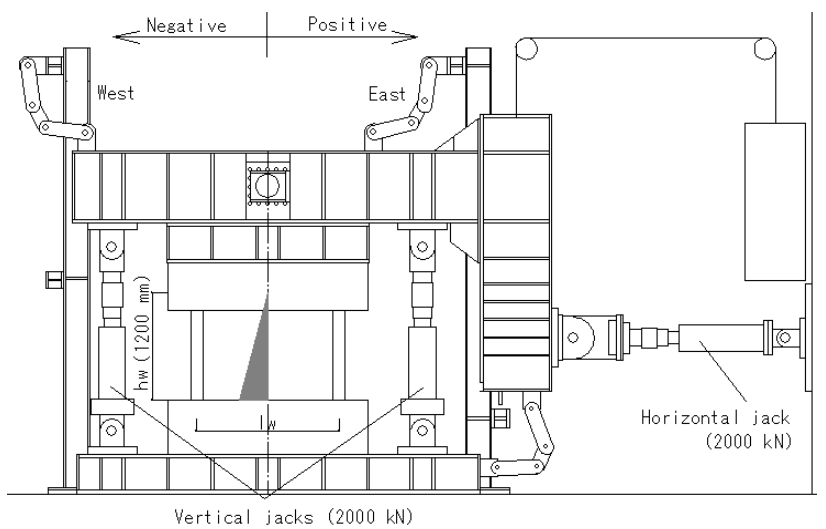

Fig. 3 Schematic view of a test set-up

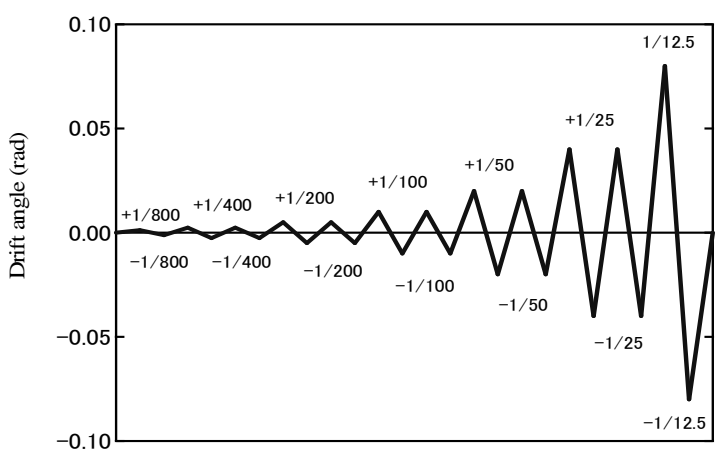

Fig. 4 Lateral loading history

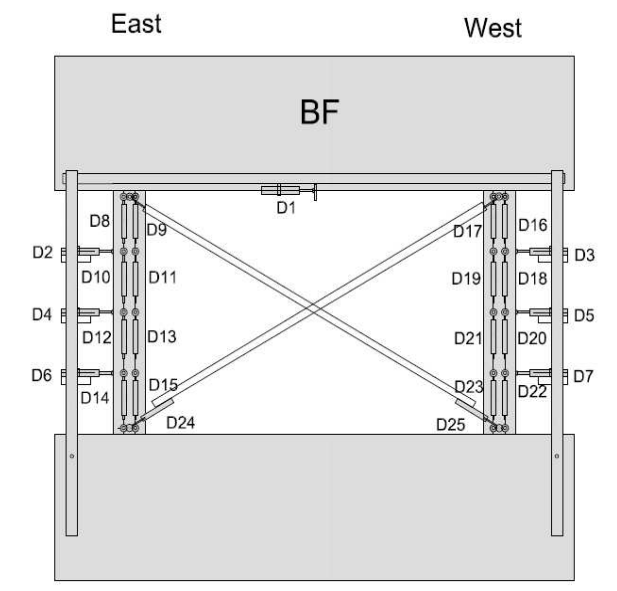

(a) Transducers set-up

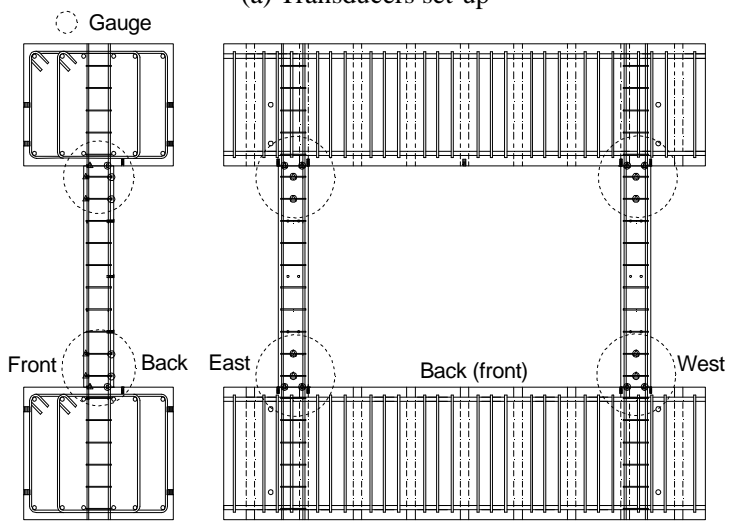

(b) The arrangement of strain gauges

Fig. 5 Measurement 


\section{RESULTS AND DISCUSSION}

\section{A. Failure Process of Specimens.}

The following is the failure mechanism for the BF specimen. The initial flexural crack was observed at the top the compressive column within $\mathrm{R}=1 / 800$. While within $\mathrm{R}=1 / 400$, flexural cracks have appeared at the top and the bottom of the both of columns. The cracks were continued propagating in these both of column within $R=1 / 200$. The initial crushing of the concrete occurred at the bottom of the compressive column has been appearing at $\mathrm{R}=1 / 100$. When the $\mathrm{R}=1 / 50$, the initial yielding of longitudinal and transverse reinforcements was detected. The cover of concrete of the column destroyed within $\mathrm{R}=1 / 25$ and the lateral strength of columns started to degrade. Finally, within $\mathrm{R}=1 / 12.5$, buckling of longitudinal reinforcement appeared at the tensile column, and therefore the specimen lost its axial resistance.

For the IF specimen, initial flexural crack was observed at the top of the tensile column during the first cycle. Separation cracks around the wall and shear cracks on the brick wall were also observed during this cycle. Flexural cracks at the top and middle of the tensile column detected within $\mathrm{R}=-1 / 400$. Initial shear at the top of the tensile column appeared within $\mathrm{R}=1 / 200$. The flexural and shear cracks in both of the columns and wall developed and during these cycles. Initial yielding of longitudinal rebar was observed within $\mathrm{R}=1 / 100$. Remarkable damage on the specimen was occurred within $\mathrm{R}=1 / 50$ such as shear failure at the top of the tensile, buckling of longitudinal rebar, initial yielding of the hoop, spalling of cover concrete of column and spalling of plaster of the wall. After the shear failure of columns, the lateral strength of specimen degraded and then specimen lost its axial resistance. Fig. 6 shows the comparison of the condition of for both of specimens at the cycle $\mathrm{R}=1 / 50$.

\section{B. Lateral Deformation of Column}

A different type of column-sway along the column height was observed on the BF and IF specimens under reversed lateral load. On the $\mathrm{BF}$ specimen, column-sway was relatively same in reversed directions since the first cycle to final loading as shown in Fig. 7(a). In the case of the IF specimen, the lateral displacement of the column in reversed direction was relatively same until the cycle $\mathrm{R}=1 / 400$, however, from the cycle, $\mathrm{R}=1 / 200$ column has a different lateral displacement shape along its height in the reversed lateral direction as shown in Fig. 7(b). The infill constrained the boundary column so that it affected to the flexibility of columns. The lateral force along the column height due to punching shear on infill also altered the lateral displacement of the boundary columns. Similar response of column-sway was also observed on the west column of the IF specimen.
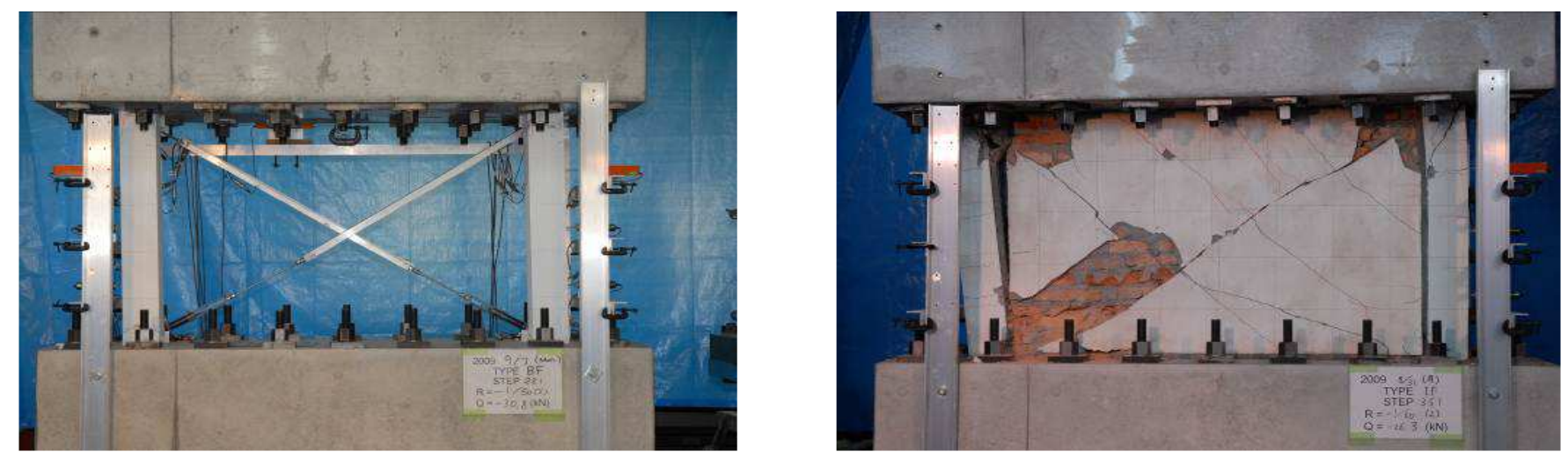

(a) Bare frame specimen

Fig. 6 Remarkable damage during the cycle $\mathrm{R}=1 / 50$

(b) Infilled frame specimen

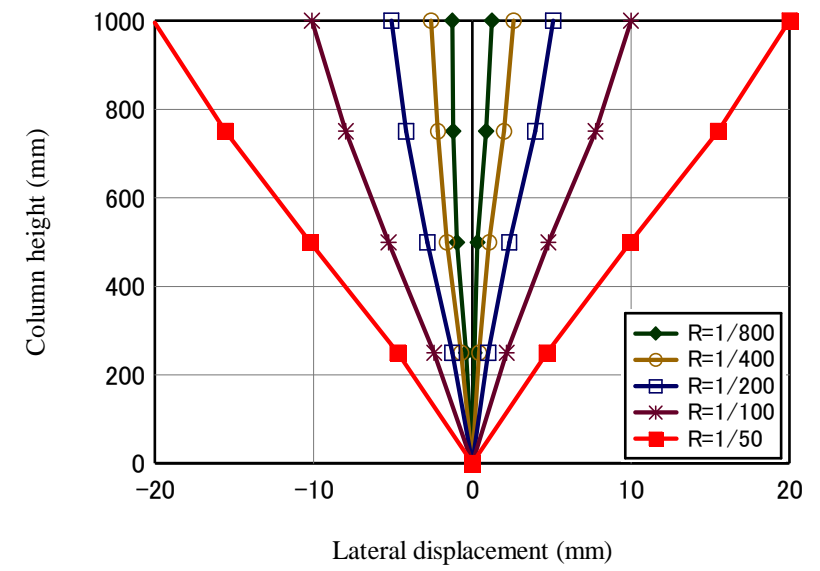

(a) BF specimen

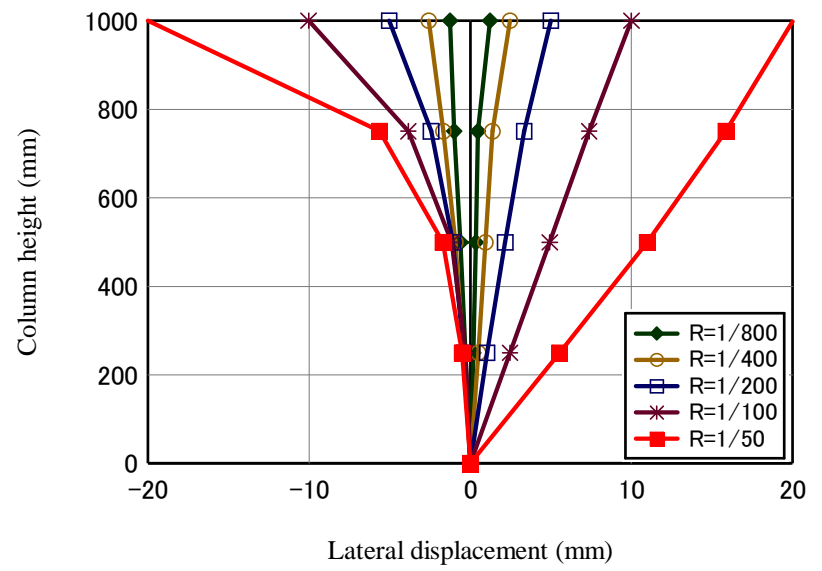

(b) IF specimen

Fig. 7 Lateral displacement of east column 


\section{Axial Deformation of Column}

Fig. 8 shows the comparison of axial deformation of the east-column for the BF and IF specimens. When the reversed lateral load applied on the upper beam of the IF specimen, the punching force in the infill transferred the additional compressive/tensile axial force on the east-column. It is shown in Fig. 8, This additional axial force caused the axial deformation on the east-column becomes different when it is compared to the axial deformation of the east-column of the $\mathrm{BF}$ specimen. The axial deformation on the west-column of the IF specimen was also different from that of the westcolumn of the BF specimen.

\section{Lateral Strength}

Fig. 9 shows the comparison of the lateral force-lateral displacement relationship curves between the BF and IF specimens, including their envelope curves. The envelope curve represents the peak values of the lateral force in each cycle of the hysteresis loop. By comparing the lateral force of both specimens, the maximum force of the IF specimen was approximately 4.7 times greater over BF specimen, but it ductility decreased up to about half. The maximum lateral force of the $\mathrm{BF}$ specimen was observed $36.8 \mathrm{kN}$ at the 20 $\mathrm{mm}$ displacement. However, for the IF specimen, the maximum force reached $174.0 \mathrm{kN}$ at the displacement of $5.02 \mathrm{~mm}$. The deformation capacity for the BF specimen is $28 \mathrm{~mm}$, while for the IF specimen is $18 \mathrm{~mm}$. The deformation capacity is a drift ratio at which the post-peak force dropped to $80 \%$ of the peak force. The deformation capacities of the IF specimen were noticed with shear failure at the top of the column, i.e., on the tensile side caused by the punching shear from the brick infill wall. This phenomenon is clearly shown in Fig. 6(b). Indeed, these results are agreeing with the progressive failure processes of the IF specimen, where the deformation capacity of the IF specimen is observed prior to the wall compression failure. These experimental results stated that the presence of the brick infill wall increases the lateral strength of the $\mathrm{RC}$ frame structure, but it decreased its ductility.

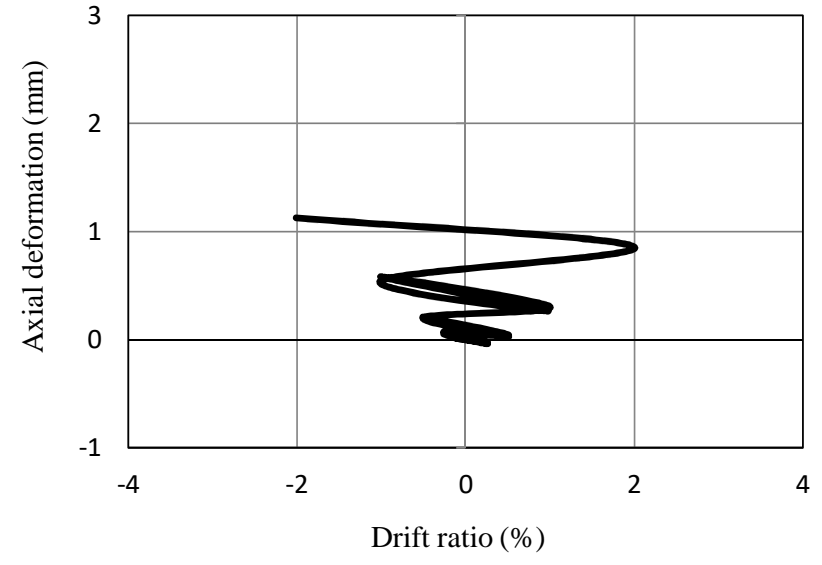

(a) BF specimen

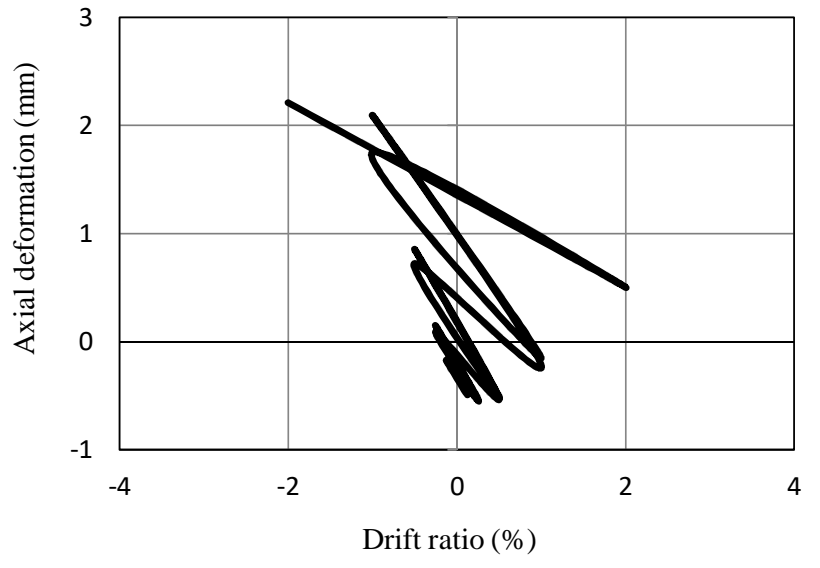

(b) IF specimen

Fig. 8 Axial deformation of the East column and drift ratio relationship

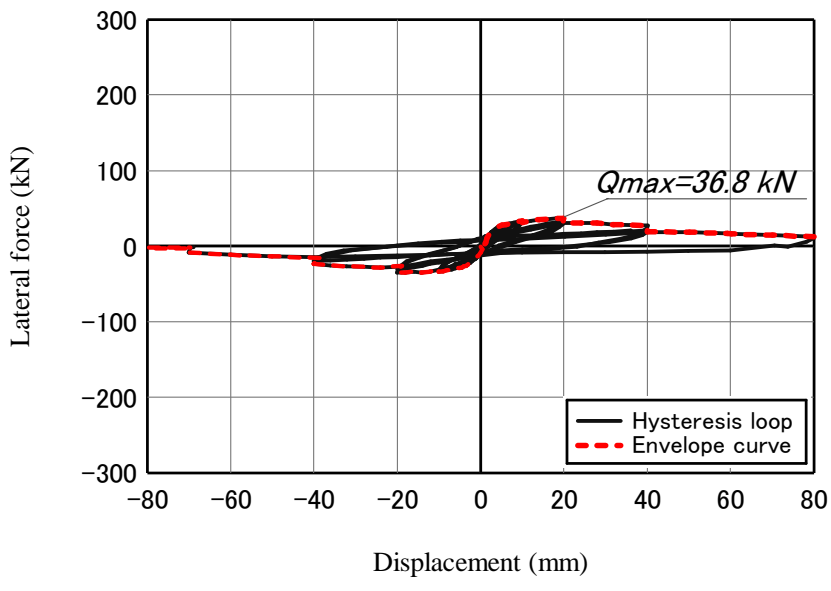

(a) BF specimen

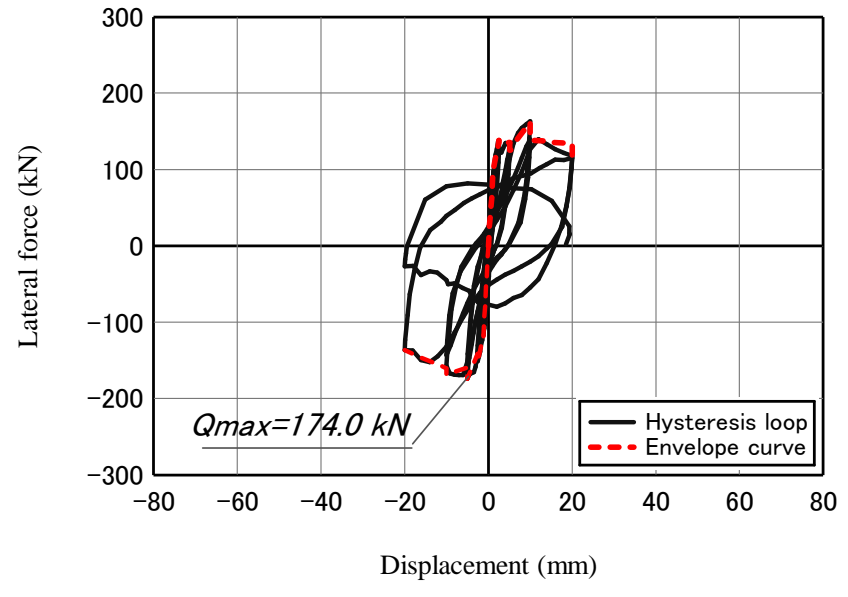

(b) IF specimen

Fig. 9 Lateral force-drift ratio relationships of the specimens with envelope curve. 


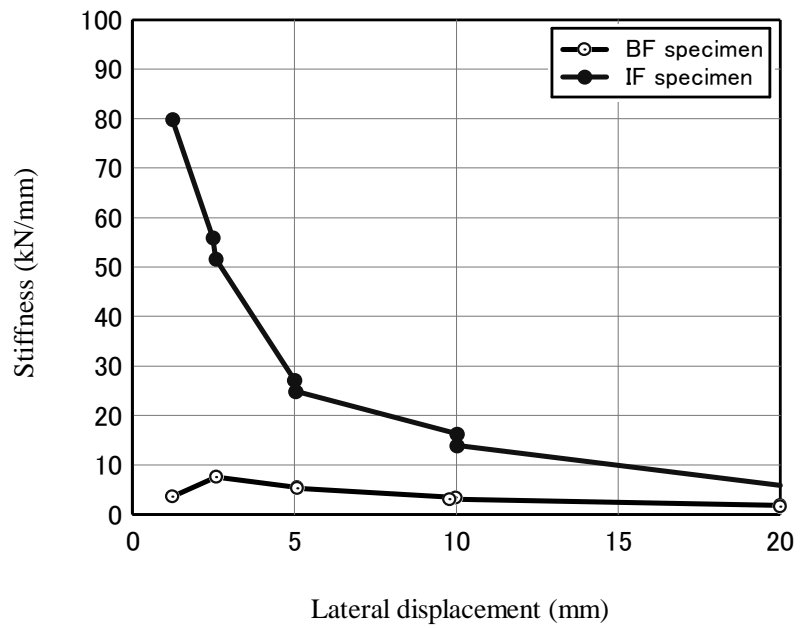

Fig. 10 Lateral stiffness

\section{E. Lateral Stiffness}

Fig. 10 shows the comparison of the lateral stiffness of the $\mathrm{BF}$ and IF specimens. It can be seen that the IF specimen exhibits the greater stiffness than the BF specimen. When the plastic hinge started developing at the ends of columns, the stiffness of the IF specimen drastically degraded.

\section{F. Dissipated Energy}

In the lateral force-displacement curve, the area within the hysteresis loop illustrates the dissipated energy [14]. By calculating the area enclosed by the hysteresis loop of the lateral force-displacement curves in Fig. 9, the comparison of the energy dissipated between the BF and IF specimens, may be drawn as is shown in Fig. 11. The brick infill in the IF specimen significantly increased the energy dissipation of the RC frame specimen. This result indicates that it could make the RC structure become less vulnerable with respect to the earthquake.

\section{IV.CONCLUSIONS}

The series experimental tests on the bare frame $(\mathrm{BF})$ and infilled frame (IF) specimens have been performed for investigating the seismic responses of the brick masonry infilled RC structure. The specimens were tested by applying the lateral static reversed cycle loading as a quasi-static of the earthquake force. The following are the summarizing of the significant findings from the current experimental works.

The significant increase of the lateral strength and stiffness were found in brick masonry infilled RC frame specimen caused by the diagonal compression strut. Unfortunately, it ductility significantly decreased.

The completely different failure mechanisms were observed between the RC bare frame (BF) and infilled RC frame (IF) specimens.

The shape of the lateral displacement and the axial elongation of the boundary columns were influenced by the existence of the brick masonry infill in RC frame specimen.

The brick masonry infill in RC frame specimen enhances it energy dissipation. This result indicates that it could make

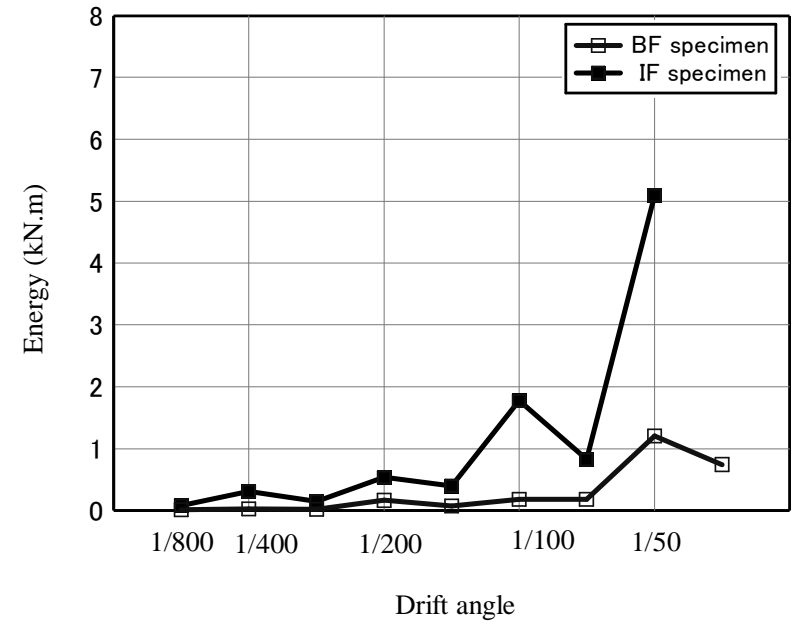

Fig. 11 Comparison of dissipated energy

the RC structure become less vulnerable with respect to the earthquake.

\section{ACKNOWLEDGMENT}

The experimental works presented in this paper was financially supported by the Ministry of Research, Technology and Higher Education (Ristekdikti), Indonesia.

\section{REFERENCES}

[1] Maidiawati and Y. Sanada, "Investigation and analysis of buildings damaged during the September 2007 Sumatra, Indonesia earthquakes," Journal of Asian Architecture and Building Engineering, vol.7(2), pp. 371-378, Nov. 2008

[2] Earthquake Engineering Research Institute (EERI), "Learning from earthquakes, the Mw 7.6 Western Sumatra earthquake of September 30, 2009," EERI special earthquake report, 2009.

[3] M. Palermo, R. R. Hernandez, S. Mazzoni, and T. Trombetti, "On the seismic behavior of a reinforced concrete building with masonry infills collapsed during the 2009 L'Aquila earthquake," Earthquake and Structures, vol.6(1), pp. 45-69, Jun 2014.

[4] A. D. Dautaj, Q. Kadiri, and N. Kabashi, "Experimental study on the contribution of masonry infilling the behavior of RC frame under seismic loading," Engineering Structures, vol. 165. pp.27-37, March 2018.

[5] Choi H., Y. Sanada, and Y. Nakano, "Diagonal strut mechanism of URM wall infilled RC frame for multi bays," in Procedia Engineering, 2017, paper 210, p. 409-416.

[6] J. Zovkic, V. Sigmund, I. Guljas. "Cyclic testing of a single bay reinforced concrete frames with various types of masonry infill," Earthquake Engineering and Structural Dynamics, vol.42(8): pp. 1131-1149, Sept. 2012. DOI: 10.1002/eqe.2263

[7] Y. Sanada and Maidiawati, "Modeling of interaction between columns and masonry infill in buildings with a column-sway mechanism," Japan Architectural Review, vol.1(1), pp.109-117, Jan. 2018

[8] N. M. Noh, L. Liberatore, F. Mollaioli, and S. Tesfamariam, "Modelling of masonry infilled RC frames subjected to cyclic load: State of the art review and modeling with OpenSees," Journal of Engineering Structures, vol. 150: 599-621, 2017. DOI:10.1016/j.engstruct. 2017.07.002.

[9] Maidiawati and Y. Sanada, "R/C Frame-Infill Interaction Model and Its Application to Indonesian Buildings," Earthquake Engineering and Structural Dynamics, vol.46(2): pp. 221-241, August. 2016. DOI: 10.1002/eqe. 2787

[10] H. Ko, H. Kim, and J. Kang, "Evaluation of seismic behavior of RC moment resisting frame with masonry infill walls," Journal of Asian Architecture and Building Engineering, vol.13(3), pp. 641-648, Sept. 2014. 
[11] B.S. Smith, "Methods for predicting the lateral stiffness and strength of multi-storey infilled frames," Building Science, vol. 2(3): 247-257, 1967. DOI: 10.1016/0007-3628(67)90027-8.

[12] JBDPA (The Japan Building Disaster Prevention Association), English Version 1st, Standard for Seismic Evaluation of Existing Reinforced Concrete Buildings. Building Research Institute, Japan, 2005.
[13] Interim testing protocols for determining the seismic performance characteristic of the structural and nonstructural component," FEMA 461, pp. 21-25, 2007.

[14] Z. Thomas, S. Alfred, and K. Bergmeister, "Energy dissipation and stiffness identification of unreinforced masonry," in Proceedings of the 15th International Brick and Block Masonry Conference, Florianopolis, Brazil, 2012 